Www.jmscr.igmpublication.org

Impact Factor (SJIF): 6.379

Index Copernicus Value: 71.58

ISSN (e)-2347-176x ISSN (p) 2455-0450

crossrefDOI: https://dx.doi.org/10.18535/jmscr/v6i7.115

Journal Of Medical Science And Clinical Research

$\underline{\text { Research Article }}$

\title{
To evaluate the effectiveness of structured teaching program of knowledge and practice regarding "First Aid" among internship students of Sumandeep Nursing College
}

\author{
Authors
}

\author{
Miss Riddhiben R Shukl ${ }^{1}$, Miss Rajvi D Soni², Miss Sweta U Vaghani ${ }^{3}$,
} Miss Heena R Vasaiya ${ }^{4}$, Miss Angel S Rathod ${ }^{5}$, Mr. Swamy P.G.N. ${ }^{6}$, Mr. Nitin Sharma ${ }^{1,2,3,4,5}$ Under Graduate Students, Sumandeep Nursing College, Sumandeep Vidyapeeth, Vadodara, Gujarat, India ${ }^{6}$ HOD of Community Health Nursing, Sumandeep Nursing College, Sumandeep Vidyapeeth, Vadodara, India ${ }^{7}$ Dept. of Mental Health Nursing, Sumandeep Nursing College, Sumandeep Vidyapeeth,Vadodara, India

\begin{abstract}
Background: Nursing management of the patient is based upon highly developed nursing assessment and clinical reasoning of skills. The nurse must know about the parameters used for First Aid, proper technique for assessment and appropriate method of documentation.

Aims \& Objectives: The aim of this study is to evaluate effectiveness of structured teaching program regarding First Aid in order to improve knowledge and practice among internship students of Sumandeep Nursing College. The objectives of the study are: (1)To assess the pre-test on knowledge and practice regarding First Aid among internship students of Sumandeep nursing college at Piparia, Vadodara.(2)To evaluate effectiveness of structured teaching program on knowledge and practice regarding First Aid among nursing students of Sumandeep nursing college at Piparia, Vadodara.(3)To find out association between pre-test knowledge and practice score with selected demographic data.

Material and Method: The selection of design depends upon the purpose of the study, research approach and variable to be studied. One group pre-test, post-test research design, which belongs to pre-experimental design, was selected to assess effectiveness of structured teaching program regarding First Aid among final year nursing students. The evaluation of structured teaching program was done through post-test on the $8^{\text {th }}$ day of implementation of structured teaching program.

Results: The " $t$ " value of knowledge and practice $(30.61 \& 29.32)$ is highly significant at 0.05 level. Hence researcher found association between pre-test and post-test practice score regarding First Aid on internship nursing students. The findings indicate variable such as Age $\left(X^{2}=0.4413\right)$, Education $\left(X^{2}=1.7\right)$, occupation of parents $\left(X^{2}=0.399\right)$, Prior attainment of any course or conference $\left(X^{2}=0.053\right)$ shows significance at 0.05 level of significance. Thus it can be interpreted that there is significance association between pre-test levels of knowledge and practice score among nursing students with their selected demographic variables so $\mathrm{H}_{2}$ ispartially accepted.

Conclusion: The study was undertaken to assess the effectiveness of structured teaching regarding First Aid in order to improve knowledge and practice among internship students of Sumandeep nursing college followed by implementation of structured teaching program. Post day was conducted $8^{\text {th }}$ day after implementation of structured teaching program using the self-structured knowledge questionnaires and practice questionnaire to find out the effectiveness. The paired ' $t$ ' test was computed between pre-test and post-test score indicate that there was improvement the level of knowledge and practice among internship students. Hence it indicates that structured teaching program was effective.
\end{abstract}




\section{Introduction}

First aid is the most important branch of Medical science. First aid is the immediate and temporary treatment given to the person who suffers an accident or any sudden illness before the medical help (aid) available, is called First Aid! First aid can also be defined as the immediate and temporary care given to an injured or sick person until the service of a qualified doctor are obtained.

\section{Objectives of the Study}

1. To assess the pretest knowledge and practice regarding First Aid among the internship students.

2. To evaluate the effectiveness of structured teaching program of knowledge and practice regarding First Aid among internship students.

3. To find correlation between pretest knowledge and post-test practice of internship students at Sumandeep Nursing College.

4. To find out association between pretest knowledge and practice scores with selected demographic variables.

\section{Hypotheses}

$\mathbf{H}_{1}$ : There will be significant increase in the post test knowledge scores as compared to pretest knowledge scores regarding First Aid among internship students at Sumandeep Nursing College, Piparia, Vadodara.

$\mathbf{H}_{2}$ : There will be significant improvement in post-test practice scores as compared to pretest practice scores regarding First Aid among internship students at Sumandeep Nursing College, Piparia, Vadodara.

$\mathbf{H}_{3}$ : There will be significant association in pretest knowledge scores with selected demographic variables regarding First Aid.

$>\mathbf{H}_{4}$ : There will be significant association in pretest practice scores with selected demographic variables regarding First Aid.

\section{Methodology}

Research approach: experimental evaluative approach

Research Design: One group pre-test, post-test research design

\section{Variables under the Study}

Independent variables: In this study, the independent variable is structured teaching program regarding First Aid.

Dependent variables: In this study, the dependent variable is knowledge and practice of internship students on First Aid.

Research Setting: The study will be conducted in Sumandeep nursing college, Piparia, Vadodara.

Population: All nursing students of $3^{\text {rd }}$ year GNM and $4^{\text {th }}$ year B.Sc. nursing students.

Sample and Sampling Technique: The sample for the present study was internship students of $3^{\text {rd }}$ year GNM and $4^{\text {th }}$ year B.Sc. nursing students. The sample size constitutes 60 internship students from Sumandeep nursing college who fulfill the inclusive criteria.

\section{Data Collection Techniques and Tools}

Structured knowledge and practice questionnaire

\section{Data Collection Tools:}

Section 1: Demographic variables include characteristics of Internship students of sumandeep college of nursing, such as Age, Education, Occupation, Attended prior courses or conferences regarding "first aid", internship students

Section 2:Self structured questionnaire was used to assess knowledge regarding First Aid.

Section 3:Self structured questionnaire was used to assess practice regarding First Aid.

\section{Results}

Findings are organised in the following section Section I: Frequency \& Percentage distribution of socio demographic variables.

Distribution of the respondents according to age shows that among 60 participants $43(71.66 \%)$ belonged to the age group of 20-23 years, $16(26.67 \%)$ belonged to the age group of $24-26$ years, $1(1.67 \%)$ belonged to the age group above 
26 years. Distribution of the respondents according to education shows that among 60 participants $30(50 \%)$ were having education of General Nursing Midwifery and 30(50\%) were having education of bachelor of science in nursing. Distribution of the respondents according to occupation of parents shows that among 60 participants $20(33.33 \%)$ were health professionals, $15(25 \%)$ were business people, $15(25 \%)$ were in teaching profession and $10(16.67 \%)$ belonged to other professions. Distribution of the respondents according to attainment of prior course of nursing conference shows that among 60 participants $5(8.33 \%)$ belongs to students who have attended conference and 55(91.67\%) belong to group of students who did not attend any conferences or courses.

\section{Section II: Analysis of pre-test knowledge \& practice scores regarding First Aid.}

The overall distribution of Pre-test knowledge regarding First Aid shows that among 60 participants $0(0 \%)$ had poor pre-test knowledge and practise, 52(87\%\%) had average pre-test knowledge and 53(88.33) had average pre-test practise scores, $8(13 \%)$ had good pre-test knowledge score and $7(11.67 \%)$ had good pre-test practice scores about First Aid.

N=60
\begin{tabular}{|l|c|c|c|c|}
\hline Category & \multicolumn{2}{|c|}{ Pre-test Knowledge } & \multicolumn{2}{c|}{ Pre-test Practice } \\
\cline { 2 - 5 } & Frequency & Percentage & Frequency & Percentage \\
\hline Poor & 0 & 0 & 0 & 0 \\
\hline Average & 52 & 87 & 53 & 88.33 \\
\hline Good & 8 & 13 & 7 & 11.67 \\
\hline Total & 60 & 100 & 60 & 100 \\
\hline
\end{tabular}

Section III: Effectiveness of structured teaching program on knowledge and practice scores regarding First Aid.

\begin{tabular}{|l|c|c|c|c|c|}
\hline \multicolumn{2}{|l|}{ Variables } & Mean & $\begin{array}{c}\text { Mean } \\
\text { difference }\end{array}$ & $\begin{array}{c}\text { Standard } \\
\text { deviation }\end{array}$ & t-value \\
\hline \multirow{3}{*}{ Knowledge } & Pre-test & 13.13 & \multirow{2}{*}{11.28} & 11.93 & 7.32 \\
\cline { 2 - 3 } & Post-test & 24.41 & & \\
\hline \multirow{2}{*}{ Practice } & Pre-test & 9.63 & \multirow{2}{*}{8.55} & 8.91 & 7.08 \\
\cline { 2 - 3 } & Post-test & 18.18 & \multicolumn{2}{|c}{} \\
$\mathbf{t}(\mathbf{5 9 , 0 . 0 5}$ level $)=\mathbf{1 . 6 7}$
\end{tabular}

According to this table, obtained $\mathrm{t}$ value for knowledge is (7.32) is greater than the table value of 1.67 at 0.05 level of significance. Hence there is significance difference exists between pre-test \& post-test knowledge scores of internship students. Therefore $\mathrm{H}_{1}$ is accepted.The obtained $\mathrm{t}$ value for practice is (7.08) is greater than the table value of 1.67 at 0.05 level of significance. Hence there is significance difference exists between pretest \& post-test practice scores of internship students. Therefore $\mathrm{H}_{2}$ is accepted.

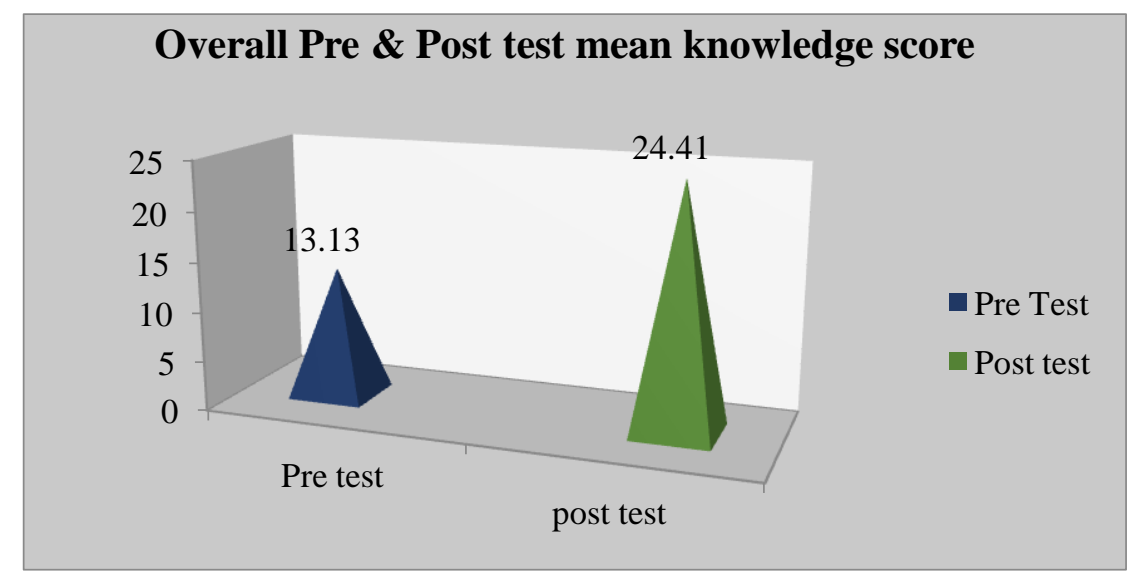

Comparison of overall pre \& post-test mean knowledge scores 


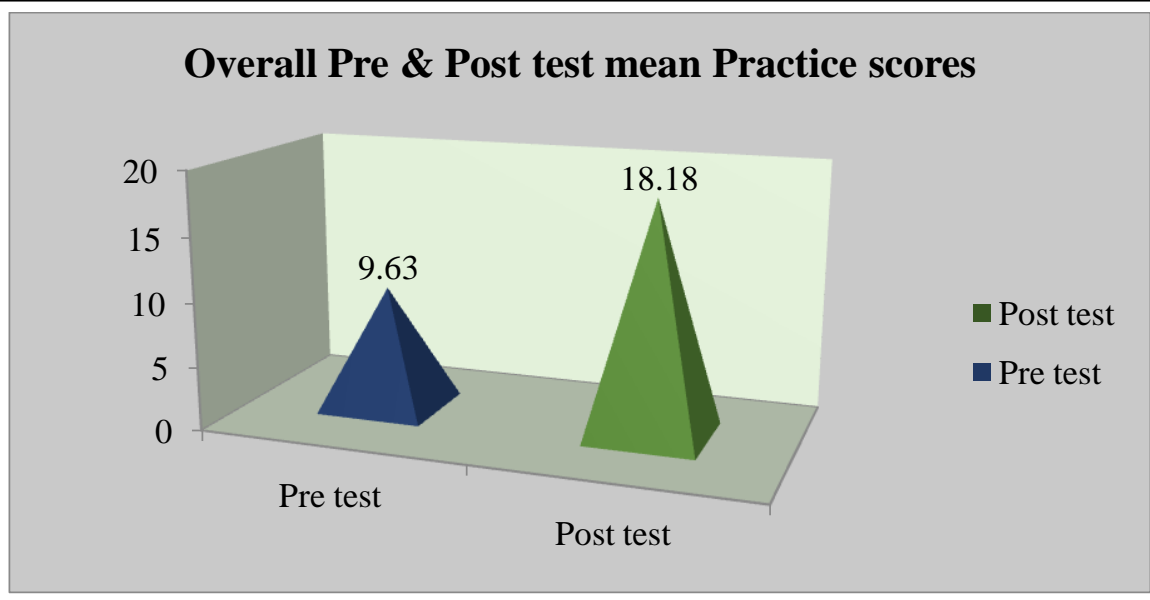

Comparison of overall pre $\&$ post-test mean practice scores

Section IV: Association between pre-test knowledge and practice scores with selected demographic variables.

This section deals with the findings of association between various demographical variables with their pre-test knowledge and practice score regarding First Aid among internship students. To test the association between pre-test knowledge and practice level with selected demographic variable, following hypothesis was formulated.

$\mathrm{S}=$ Significant at 0.05 level

The values that are obtained is chi square value in the variables such as age $\left(X^{2}=0.4413\right)$, education $\left(X^{2}=1.7\right)$, occupation of parents $\left(X^{2}=0.399\right)$ and the value for prior attainment of any course or conference on First Aid is $\left(\mathrm{X}^{2}=0.053\right)$. The obtained value is lesser than the table value at 0.05 level of significance was rejected. The obtained $\chi^{2}$ value 0.4413 is less than the table of $\chi^{2}$ at 0.05 levels for age. Hence the obtained $\chi 2$ value is insignificant. There is insignificant association between education and pre-test knowledge along with practise. The obtained $\chi 2$ value 0.399 is less than the table of $\chi^{2}$ at 0.05 level for occupation of parentsand its relation with pre-test knowledge along with practise. Thus it is insignificant. The obtained $\chi^{2}$ value 1.7 is more than the table of $\chi^{2}$ at 0.05 . Hence the obtained $\chi^{2}$ value is insignificant. There is insignificant association between prior attainment of conference or courses with pre-test knowledge along with practise. The $\chi^{2}$ value 0.053 is less than the table value of $\chi^{2}$ value at 0.05 . Thus it is considered insignificant.

\section{Recommendations}

Based on the finding of the present study recommendations offered for the future study are:

1. The study can be replied in large sample for better generalization.

2. A similar study can be conducted with different teaching strategies like structured teaching planning.

3. A similar study can be done regarding knowledge and practice regarding First Aid among ICU staff.

4. A comparative study between GNM and B.Sc. nursing student's knowledge and practice on First Aid.

5. This study will be reference for research scholars.

\section{Conclusion}

The present study assessed the knowledge and practice regarding First Aid examination among internship students at Sumandeep nursing college, Piparia, Vadodara and found that the majority have average knowledge and practice regarding First Aid. After structured teaching program on First Aid there was significant improvement on knowledge and practice of the internship students regarding First Aid. The study concluded that the structured teaching program was effective in improving their knowledge and practice reading First Aid.

According to pre-test $87 \%$ have average knowledge \& $13 \%$ have good knowledge and $88.33 \%$ have average practice and $11.67 \%$ have 
good practice reading First Aid. According to post-test $96.67 \%$ have good knowledge \& $3.33 \%$ have average knowledge and no one have poor knowledge and $100 \%$ have good practice and no one have average and poor practice regarding First Aid, which was higher than pre-test knowledge and practice score range.The mean post-test knowledge score also was higher than mean pretest score.

There was significant difference in knowledge and practice scores regarding First Aid among internship students at Sumandeep Nursing College, Piparia, Vadodara, thus H1 is accepted.

\section{Reference}

1. N.K Anand. Shikha Goel,"first Aid", ALTBS Publishers, India, First edition: 2007. Page no:2-3

2. Wikipedia, the free encyclopaedia, first aid manual: $9^{\text {th }}$ edition dorlingkindersley. 2009.ISBN 9781405335379.

3. CPR Seattle blog, "duct tape for the win! Using household items for first aid needs." Learn more about safety, CPR and first Aid published on October 12, 2012

4. Ababa Ad .dis. First Aid extension package. Federal Democratic republic of Ethiopia, ministry of health .2003 sep. Available At: http://cnhed.ei.columbia.edu/traning/docu ments/First_Aid.pdf

5. Indian red crosses [online], 2009, http://www.indianredcross.com.

6. Arbon Paul, Hayes Jo. First Aid and harm minimisation for victims of road trauma. A population study. 2007 jun. Available at: http://www.ambulance.net.av/clicktosave/ www/docs/Australian_population_sudy_o n_victims_of_Road_Trauma.pdf.

7. NCRB Report, "Chennai road are most dangerous in India, "New India express, July, 2012. Available At: ibnlive.in.com/news/Chennairoads/269355-62-13html.
8. Jones G's Journal of accident and emergency nursing, volume-6 ISSN-09652302, published on April 1998, Scotland. Available At: http://mbbsdost.com/Forignbodies-eye-Accident-emergency-nursingJones-G-1998-Apr/pubmed/12446540

9. Dr. Khurshi Khowaja, Utilization of king's interacting system framework and theory of goal attainment with new multidisciplinary model: Clinical Pathway, March 2006, Volume 24 Number 2.

10. Tannvik TD, Bakke HK, Wisborg T.A systematic literature review on first aided provided by laypeople to trauma victims. Acts Anaesthesiologica Scandinavica. 2012 Nov1;569(10):1222-7. Available At: http://www.ncbi.nlm.nih.gov/pmc/aeticles/ PMC3495299/ 